\title{
非線 形コンベアモデル
}

\author{
平 瀬健*
}

\section{1. まえがき}

高橋は人口分布の動的なモデルとして「コンベアモ デル」とよばれる線形分布定数形モデルを導入した ${ }^{11}$. このモデルは簡単な構造をもちながらす問題の本質を 巧みにとらえている. 本稿では，乙のモデルの出生率 に新しく全人口に依存する負のフィードバックを付加 した場合を考察した．乙の場合モデルは非線形の境界 值問題となるが, 初期分布に依存しない安定な定常解 が解析的に得られるととを示した. このような定常解 は元の線形モデルには依存しないあのであり, 出生制 御の効果を表わすあのとして興味梁いと思われる.

\section{2. コンベアモデル}

コンベアモデルはつぎのような 1 階の偏微分方程式 の境界値問題として定式化される.

$$
\begin{aligned}
& \frac{\partial}{\partial t} x(t, a)+\frac{\partial}{\partial a} x(t, a)=-m(a) x(t, a) \\
& x(t, 0)=\int_{0}^{\infty} x(t, a) b(a) \mathrm{d} a
\end{aligned}
$$

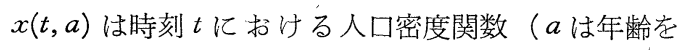
表わす), $m(a), b(a)$ は扔の打の年齢 $a$ に打矽亡 係数之出生係数である. 境界值問題 $(1),(2)$ の解は つぎのように表わされる.

$$
x(t, a)=\sum_{i=1}^{\infty} c_{i} e^{\lambda_{i}(t-a)} p(a)
$$

ただし $c_{i}$ は初期分布に依存した数で， $p(a)$ は

$$
p(a)=\exp \left[-\int_{0}^{a} m(\xi) \mathrm{d} \xi\right]
$$

で与元られる。 $p(a)$ は年齢 $a$ まで生き残る確率を表 わしているととは容易にわかる，また $\lambda_{i}$ は

$$
1=\int_{0}^{\infty} e^{-\lambda_{i} a} p(a) b(a) \mathrm{d} a
$$

を満足する複素数で, 可算個存在する.

$$
1<\int_{0}^{\infty} p(a) b(a) \mathrm{d} a
$$

のとき, 正の実数で ( 5 )式を満すすのが存在するので (3) 式の形から明らかなように解は特別な場合を除き 指数関数のオーダーで無限に増大する. また

$$
1>\int_{0}^{\infty} p(a) b(a) \mathrm{d} a
$$

のときは(5)式を満すすべての $\lambda_{i}$ の実部は負となる ので, 解 (3) は指数関数のオーダーで 0 に収束する. したがって (3)式が定常的な分布を表わすためには

$$
1=\int_{0}^{\infty} p(a) b(a) \mathrm{d} a
$$

でなければならない。

\section{3. 非線形コンベアモデル}

ここで (2)式の代わりにつぎのような境界条件を考 えよう。

$$
x(t, 0)=\int_{0}^{\infty} x(t, a) b^{(n)}(x(t, a), a) \mathrm{d} a
$$

ここで $b^{(n)}(x, a)$ は $x(t, a)$ に依存してつぎのように 定まる $a$ の関数である.

$$
b^{(n)}(x, a)=\max \left(0, b(a)\left(1-\varepsilon \int_{0}^{\infty} x(t, \xi) \mathrm{d} \xi\right)\right)(10)
$$

$\varepsilon$ は適当な正の数である. (10)式は全人口が増大する とさまざまの要因（食糧不足, 環境悪化等)によって 出生率が減少することを表わしたものと考えてあよい し，あるいは人口抑制のための人為的な政策を表わす あのと考えてもよい.

境界值問題 $(1),(9)$ 式の定常解 $x=x^{0}(a)$ を求め よう. (1)式化代入すると

$$
\frac{\partial x^{0}}{\partial a}=-m(a) x^{0}
$$

これより $(4)$ 式で与えられる $p(a)$ を用いると

$$
x^{0}(a)=c p(a)
$$

と表わされる. (12)式を(9)式代入すると

$$
c=\frac{\int_{0}^{\infty} p(a) b(a) \mathrm{d} a-1}{\varepsilon \int_{0}^{\infty} P(a) \mathrm{d} a \cdot \int_{0}^{\infty} P(a) b(a) \mathrm{d} a}
$$

をうる(注 1)。したがって条件(6)が成り立っている

* 近畿日本鉄道(株) 大阪市天王寺区上本町 6-1-1

** 大阪大学基礎工学部 豊中市待兼山町 1-1 


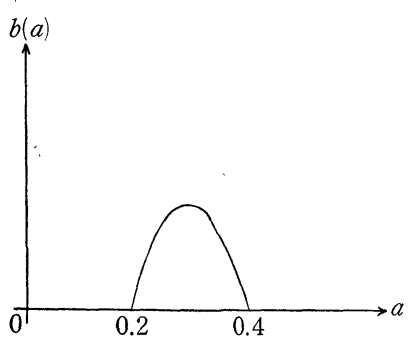

Fig. 1 Birth rate

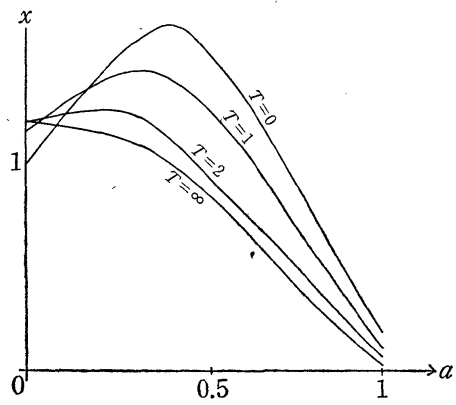

Fig. 2 Result of the simulation

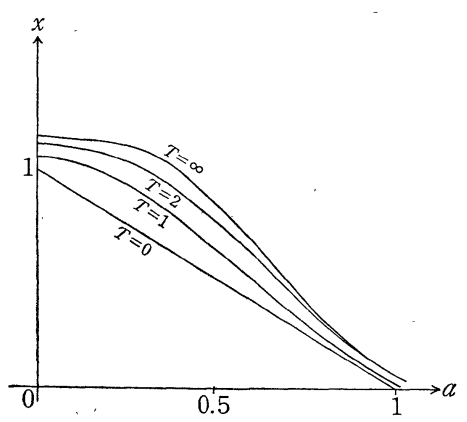

Fig. 3 Result of the simulation
とき $c>0$ となり，恒等的に0ではない定常解が一 意的に(12)，(13)式で与えられる.（6)式が成り立た ないときは定常解は恒等的に 0 以外のものは存在しな いととは容易にわかる。

定常解(12)，(13)式が安定であるととを示そう，そ のため(1)，(9)式の解をつぎのようにおく.

$$
x(t, a)=x^{0}(a)+y(t, a)
$$

ここで $y(t, a)$ は微小な摂動項である. (14)式を(1) 式に代入し(11)を用いると

$$
\frac{\partial y}{\partial t}+\frac{\partial y}{\partial a}=-m(a) y
$$

また $(9)$ 式に代入して $y(t, a)$ の 2 次の項を無視する と

$$
\begin{aligned}
& y(t, 0)=\int_{0}^{\infty} y(t, a) f(a) \mathrm{d} a \\
& f(a)=\left(1-\varepsilon \int_{0}^{\infty} x^{0}(\xi) \mathrm{d} \xi\right) b(a)-\varepsilon \int_{0}^{\infty} x^{0}(\xi) b(\xi) \mathrm{d} \xi
\end{aligned}
$$

をうる. $x^{0}(a)$ の形より

$$
f(a)=\frac{b(a)}{\int_{0}^{\infty} p(\xi) b(\xi) \mathrm{d} \xi}-\frac{\int_{0}^{\infty} p(\xi) b(\xi) \mathrm{d} \xi-1}{\int_{0}^{\infty} p(\xi) \mathrm{d} \xi}
$$

と表わされる。 (15)，(16)式は $f(a)$ をb(a) 亿代え れば線形コンベアモデル(1)，(2)式と同じ形をして いる. 一方仮定 $(6)$ より

$$
\int_{0}^{\infty} p(a) f(a) \mathrm{d} a=2-\int_{0}^{\infty} p(a) b(a) \mathrm{d} a<1
$$

したがって線形コンベアモデルの安定判別法に従え ば，(15)，(16)式の解 $y(t, a)$ は $t \rightarrow \infty$ で 0 に収束す る. このととは定常解 $x^{0}(a)$ 亿微小な摂動が加わっ ても，それは時間と共に減少するととを示している.

(注 1) これより $1-\varepsilon \int_{0}^{\infty} x^{0}(a) \mathrm{d} a=\frac{1}{\int_{0}^{\infty} p(a) b(a) \mathrm{d} a}>0$ とな
すなわち定常解 (12)，(13）は，（6）式を満す任意の $b(a), m(a)$ と, 任意の $\varepsilon$ 亿対して安定である.

\section{4. 例}

計算機シミュレーションの結果を示そう. 平均寿命 を $a=1$ とし， $b(a)$ をつぎのようにおく.

$$
b(a)= \begin{cases}-\kappa(a-0.2)(a-0.4), & 0.2 \leq a \leq 0.4 \\ 0, & a>0.4, \quad a<0.2\end{cases}
$$

すなわち $(0.2 ， 0.4)$ の年齢帯のみに $a=0.3$ をピー クとする出産能力をすつと仮定する (Fig. 1 参照). 死亡係数は

$$
m(a)=0.1 a^{2}
$$

とする. Fig. 2 は $\varepsilon=1 / 10, \kappa=15$ ，初期分布を

$$
x(0, a)=-a+1
$$

とした場合である. Fig. 3 は $\varepsilon=1 / 2, \kappa=15$ ，切期 分布を

$$
x(0, a)=1+\sin \frac{4 \pi a}{3}
$$

とした場合である．いずれの場合あ約 3 世代で定常分 布に落ち着き，初期分布には依存しないことが確かめ られた。

\section{5. むす び}

コンベアモデルの出生率に非線形を導入し, 線形モ デルに存在しない安定な固有定常分布の存在を理論 的, 数値的に確かめた. 実際問題としては出生率だけ ではなく，死亡率にあ非線形性を導入するととが望ま しいが，それは今後の問題である. 終わりに有益なで 討論をして頂いた坂和愛幸教授，西義和氏に感謝す る.

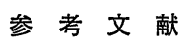

1）高橋安人：個体数の力学 [II]，計測之制御， 11-9, 797/ 804 (1972)

る. 